\title{
Pamćenje u službi budućnosti
}

\author{
Jasna Ćurković Nimac*, Jerko Valković***
}

\begin{abstract}
Sažetak
Uz kognitivnu i epistemološku dimenziju pamćenja autori posebnu pozornost pridaju normativnoj $i$ formativnoj dimenziji pamćenja, odnosno pedagoškopraktičnomu aspektu. Polazeći od teze da je povezanost pamćenja i identiteta ključni izvor normativnosti, autori nastoje pokazati da društvena i politička stabilnost ovisi o tome kako se odnosimo prema pamćenju. Budući da naše hrvatsko društvo na poseban način karakterizira s jedne strane "manjak", a s druge "višak" pamćenja, autori ukazuju na nužnost iznalaženja prave mjere između dvaju ekstrema.

Nakon uvodnog dijela u kojem se ukazuje na neke fenomenološke pretpostavke koje je potrebno uzeti u obzir kada se raspravlja o etici pamćenja, u radu se analizira povezanost pamćenja s moralnim vrijednostima i odgovornostima. Tvrdeći da je pamćenje po sebi nešto dobro i stoga vrijedan sastavni dio dobrog života, autori nastoje ukazati na određene etičke kriterije pamćenja koji bi trebali jamčiti "budućnost pamćenja". Uz zabrinutost zbog manipulacija pamćenjem, u radu se ističu pozitivni pomaci na tragu promjene memorijske paradigme koja se aktualizirala krajem 20. stoljeća.
\end{abstract}

Ključne riječi: etika, pamćenje, budućnost, društvo, pravednost

\section{Uvod}

Prihvatimo li s jedne strane tvrdnju Duncana Bella, koji kaže da »nasilje mora stajati u središtu bilo kojeg razumijevanja pamćenja i politike «1 (Bell, 2009, 345-360), i ideju da je konflikt ono što u nekom smislu etiku čini nužnom te da su nam potrebna etička pravila prioriteta kako bismo živjeli u harmoniji postaje jasno otkuda zanimanje etike za pamćenje. ${ }^{2}$ Prema Mery Midgley sukobi ili

* Izv. prof. dr. sc. Jasna Nimac Ćurković, Hrvatsko katoličko sveučilište. Adresa: Ilica 242, 10000 Zagreb, Hrvatska. E-adresa: jasna.curkovic@unicath.hr

** Izv. prof. dr. sc. Jerko Valković, Hrvatsko katoličko sveučilište. Adresa: Ilica 242, 10000 Zagreb, Hrvatska. E-adresa: jerko.valkovic@unicath.hr

1 Citati na hrvatskom jeziku iz engleskih izvornika prijevod su autora ovoga članka.

2 Neki autori razlikuju pamćenje i sjećanje, pa se tako pamćenje smatra skladištenjem sadržaja prošlosti, odnosno »psihološkim procesom usvajanja i zadržavanja novih sadržaja«, a sjećanje se 
konflikti kojima su ispunjeni mitovi zapravo su usmjereni na to da objasne zašto ljudi moraju živjeti po pravilima koja se katkad sukobljavaju s njihovim željama. Stoga ideja da pamćenje može prouzročiti neki "kvar" u našim odnosima i našem osobnom životu te da moramo naučiti ophoditi se s njime, stoji u temeljima etike pamćenja. To je zapravo stara nova tema, jer pitanje kako se sjećati kako bismo osigurali pojedinačno savršenstvo te zdravo i pravedno društvo raspravlja se sve od Platona i Aristotela. Ono što je novo jesu mnemonički mehanizmi ili mnemotehnike, modaliteti politike pamćenja i forme koje ono zadobiva, posebno nakon Holokausta. Početkom osamdesetih godina govorilo se sa zabrinutošću o pamćenju, a danas je u društvenim i humanističkim znanostima ta tema postala toliko dominantnom da se govori i o "višku pamćenja", "tiraniji pamćenja", "kultu pamćenja”, “epidemiji pamćenja” i sl. Gotovo da je diskurs o pamćenju generirao neki oblik institucionalizacije, pa tako imamo znanstveni pravac nazvan memory studies, multidisciplinarne centre za proučavanje ili čuvanje pamćenja, časopise poput Memory Studies, Memory\&History i sl. te mnoštvo literature o toj temi, tako da se zadnjih petnaestak godina promišlja i o samim uzrocima koji su potaknuli erupciju teme pamćenja. Na tragu rečenoga neki znanstvenici se pitaju nije li »memorijski boom dosegnuo svoj vrhunac te ce uskoro početi jenjavati« (Rosenfeld, 2009, 123). To se sigurno neće dogoditi u Hrvatskoj, jer ta tema u znanstvenom diskursu nije ostavila dubljeg traga (malo je knjiga o toj temi, većinom su to prijevodi djela stranih autora te samo nekoliko primijenjenih studija o pamćenju), što uistinu čudi s obzirom na to da smo stalno nekako "nasukani" u prošlosti i pamćenjem se bavimo u dnevnopolitičkim raspravama. K tomu, očito je da su u stvarnosti etika i politika pamćenja uistinu globalni fenomen. Goruća pitanja o tome kakve trebaju biti naše komemoracije ili kakav stav naše društvo treba zauzeti prema nekim važnim povijesnim događajima, na koji način počinitelje zločina dovesti pred lice pravde, kao i kontroverzije oko povijesnih udžbenika ili spomenika, nastojanja oko povijesnih odšteta ili isprike za zločine iz prošlosti, prepoznajemo svugdje u svijetu i ta pitanja uglavnom u sebi sadrže etičku komponentu.

Posebnost etičkog pristupa pamćenju i doprinos etike toj temi sastoji se u tome što, za razliku od društvenih znanosti, pa i humanističkih, poput povijesti, koje su zainteresirane za pamćenje kao dio prošlosti, etika je pamćenja, kao i etika općenito, više zainteresirana za dimenziju sadašnjosti i budućnosti u diskursu o pamćenju. Naime, većina autora iz područja studija o pamćenju, tzv. memory studies, povezuje prošlost i sadašnjost na tragu misli kako prošlost nije mrtva niti spava (Lowenthal, 1995, xxv), nego aktivno djeluje u sadašnjosti preko našeg sjećanja i imaginacije. U svojoj knjizi Pamćenje John Scanlan kaže da smo mi »putnici sadašnjosti, odnosno putnici koji ne idu u daleku prošlost, nego u sadašnjost koja dolazi od prošlosti« (Scanlan, 2015, 17). Pamćenje je dakle

definira kao aktualiziranje skladištenih sadržaja, odnosno »obnavljanje predodžbe o prošlom u svijesti«. Pod kolektivnim sjećanjem razumijevaju se uspomene određene zajednice, a kolektivno pamćenje označava usmjeravajući rad na njima (Brkljačić i Prlenda, 2006, 17). 
definirajuća značajka stanja ljudskih bića ili »središnja sposobnost našeg bivanja u vremenu; ono je pregovaranje između prošlosti i sadašnjosti kojim definiramo svoje pojedinačno i kolektivno ja« (Olick, 2003, 15). Jednostavno se može reći kako je pamćenje pokušaj da prošlost posadašnjimo i uprisutnimo. Kao da pamćenje u ime vječnosti vodi stalnu borbu protiv vremena. Stoga ne čudi što je pamćenje u mnogim kulturama shvaćeno kao opreka prema smrti. Ta takozvana prezentističko-instrumentalna perspektiva dio je Halbwachsove teze o interesima sadašnjosti koji su prisutni u svakoj rekonstrukciji prošlosti (na tragu Durhemove paradigme društvene konstrukcije stvarnosti) te Freudove teze o funkcionalnoj prirodi pamćenja koje stalno rovari po sadašnjosti i izaziva diskontinuitet ili prekid, jer neki dijelovi prošlosti nisu na odgovarajući način integrirani u naše svjesno iskustvo. Stoga se čini da je u pravu Aleida Assman, koja u svojoj knjizi Transformations of Modern Time Regimes, o temporalnoj dinamici i promjenama kroz povijest u odnosu prema prošlosti i budućnosti, zaključuje da je budućnost postala izvorom zabrinutosti i izgubila svoj sjaj, koji je primjerice imala u vrijeme razdoblja moderne, a čovječanstvo je postalo zaokupljeno prošlošću (Assman, 2013). Na je istom tragu i Andreas Huyssen, koji kaže da je sadašnja opsesija pamćenjem »znak krize strukture temporalnosti koja je obilježila vrijeme moderne sa slavljenjem novoga kao utopijskoga, radikalnoga i nesvodljivo drugoga « (Huyssen, 1995, 6).

S druge strane, na praktičnoj razini, neki politički akteri i brojni aktivisti naglasak posebno stavljaju na potragu načina i modela bavljenja prošlošću koji se fokusiraju na izgradnju bolje budućnosti. Pamćenje se u tom smislu shvaća ponajprije kao materijal za konstrukciju identiteta, individualnoga i nacionalnoga. Gledanje na pamćenje-koje-oblikuje-budućnost stoga je temelj studija o kolektivnom pamćenju i demokraciji, ljudskim pravima i tranzicijskoj pravdi, osveti, pitanjima pomirenja, oprosta i sl. Oni koji se bave tranzicijskom pravdom, koja se posljednjih desetljeća pojavljuje u sklopu različitih modela i metoda bavljenja prošlim konfliktima, posve su se usmjerili na preobražavanje nasilja iz prošlosti i konflikata prema mirnoj budućnosti, pomirenju i demokratskoj kulturi. Mehanizmi tranzicijske pravde, kao truth commissions, reparacije i sudovi, koriste se diljem svijeta u različitim kontekstima koji odgovaraju lokalnim praksama i kulturnim vrijednostima, kako bi prošlost stavili u službu budućnosti. Slično tomu, aktivisti se koriste pamćenjem kako bi zahtijevali bolju budućnost, a pravnici, osobito oni koji se bave međunarodnim pravom, sve češće gledaju na primjere iz prošlosti kako bi iznašli rješenja za sadašnjost koja može postaviti čvrst presedan za budućnost.

Na tom tragu i ovaj rad nastoji ukazati na činjenicu kako etika svaki govor o prošlosti i pamćenju ujedno preobražava u govor o sadašnjosti i budućnosti. Pritom se ona, etika pamćenja, mora čuvati opasnosti liberalnog a-historicizma, $\mathrm{s}$ jedne strane, (prema kojem je prošlost teret kojeg se moramo osloboditi kako bismo krenuli u budućnost bez utega), te opasnosti parazitiranja na starim ranama ili nostalgičnog prianjanja uz prošlost, s druge strane (stalnog lamentiranja nad prošlosti bez nastojanja da prošlost aktivno iskoristimo za bolju budućnost). 


\section{Granice pamćenja: "prošlost je strana zemlja"}

O granicama i nepouzdanosti pamćenja već je puno rečeno, od Halbwachsove knjige Društveni okviri pamćenja i Barttletova eksperimenta s pričom The war of Ghost pa nadalje. Ukratko, pamćenje nije pouzdan epistemološki alat, jer se sjećamo selektivno, netočno, pod utjecajem svjesnoga i nesvjesnoga, imaginacije. Naša su pamćenja isprepletena s pamćenjem drugih ljudi, pod utjecajem su društvenog pamćenja i sl. »Pamćenje je uvijek problematično, često obmanjivo, ponekad podmuklo [...] sami smo periodično svjesni da je pamćenje među najkrhkijim i najkapricioznijim sposobnostima« (Yerushalmi, 1982, 5).

Narativno pamćenje nikada nije nedužno. Ono je stalan konflikt interpretacija: bojno polje konkurirajućih značenja. Pamćenje nikada nije na strani anđela. Ono lako može odvesti u krivu svijest i ideološku zatvorenost kao i u otvorenost i toleranciju (Kearney, 2004, 105).

Mnogi autori stoga upućuju na potrebu da se pamćenje pomogne historiografijom, kao “pouzdanijim epistemološkim pravcem”. Stoga je pamćenje uvijek podložno ispravcima od strane historiografije. No distinkcija između povijesti i pamćenja nije uzeta unisono. Neki autori smatraju da su ta dva koncepta posve odvojena, drugi da su izrazito bliska, a treći opet da među njima postoje minimalne razlike, pa govore o »zapamćenoj povijesti« (Lewis, 1975), »povijesnom pamćenju « (Barman, 1997). No činjenica je da su i povjesničari pod utjecajem "prezentizma" te historiografija nema nikakav ekskluzivan pristup realnomu, jer je povijesno znanje velikim dijelom posredovano preko narativa/priča i interpretacija. Stoga ne čudi sve rašireniji kriticizam u odnosu na epistemološko prekomjerno samopouzdanje i pretjeranu vjeru u povjesničara kao onog koji je slobodan od vrijednosnih sudova. Kao što kaže Vosloo, oboje, i povijest i pamćenje, ranjivi su kao rute prema prošlosti (Vosloo, 2012, 215-227). »Prošlost ostaje strana zemlja « (Hartley, 1953, 7) i moramo biti oprezni u odnosu na kriva obećanja hermeneutičkih i epistemoloških prečica prema toj zemlji.

Ograničena epistemološka struktura pamćenja upućuje na složenost fenomena pamćenja kad ga se promatra kao subjekt etičkog promišljanja (slično je primjerice s emocijama). Moralna dvosmislenost ili oprečna uloga koju pamćenja mogu igrati za pojedinca i društvo čine nužnim takvo promišljanje. Kada se ta ograničena epistemološka struktura doda moralnoj dvosmislenosti, tada u rukama imamo vrlo krhak i opasan, ali i moćan alat, koji je tijekom ljudske povijesti vrlo vješto korišten na pozitivan i negativan način, s obzirom na to da pamćenje »nije samo kanal informacija (i dezinformacija) o prošlosti; ono je također, i to primarno, medij kroz koji prošlost od nas nešto zahtijeva « (Poole, 2010, 32). Pamćenje dakle često ima dijametralno suprotnu ulogu kad se njime netko služi radi političkih ciljeva. Ono je »potaknulo nemilosrdne nasilne razdore, a bilo je u središtu pomirenja i rekonstrukcije. Korišteno je da opravda velike zločine, a ipak je središnji alat za postizanje pravde« (Booth, 2006, ix). 


\section{Moralno značenje pamćenja i povezanost s identitetom}

\section{U svojoj knjizi Lost Time David Gross piše:}

Za razliku od onoga koji se sjeća, koji nastoji biti pretjerano oprezan i davati savjete [...], onaj koji zaboravlja čini se lakši, rasterećeniji, čak i veseliji. Nadalje, pošto nije obuzet duhovima prošlosti [...], onaj koji zaboravlja nastoji krenuti novim smjerovima, eksperimentirati i improvizirati, čak, ako tako odluči, učiniti svaki trenutak ishodištem ili početkom (Gross, 2000, 54).

Prividna moć i privlačnost takvog razmišljanja prema kojem pamćenje ograničava našu dobrobit i blagostanje, podsjeća na Nietzscheov poticaj na zaborav jer zaborav prema njegovu mišljenju osigurava sreću i uspješan život. Mnogi autori međutim kritiziraju takav pristup. Miroslav Volf zbog neosjetljivosti prema širem društvenom kontekstu (Volf, 2006), a Jeffery Blustein zbog toga što bez pamćenja ne možemo preuzeti odgovornost za prošlost, a bez preuzimanja odgovornosti za prošlost propuštamo razvoj sebe i društva (Blustein, 2008).

Mnogobrojna literatura o pamćenju fokusira se na terapeutski i protektivni učinak pamćenja i stoga smatra da je zaborav nešto što dugoročno šteti, a to je i prva i osnovna lekcija psihoanalize. Na tragu aristotelovske tradicije pozitivni aspekti i učinci pamćenja često se navode kao potreba da čuvamo pamćenje. Tako se govori o terapeutskom učinku pamćenja, solidarnosti, pravdi, poučavanju i lekcijama prošlosti, empatiji, izgradnji (širega/novoga) identiteta i sl. Osim toga, pamćenje je konstitutivni dio ljudskog bića i temeljna sposobnost za naše svakodnevno funkcioniranje te u tom smislu biološka nužnost. No u moralnom smislu pamćenje nije apsolutno dobro, odnosno nije dobro uvijek i u svim okolnostima. Ono je dobro i važan je sastojak javnog i osobnog života ako poštuje određene kriterije i ostaje unutar zadanih granica. $\mathrm{Na}$ isti način, dužnosti pamćenja ili dužnosti povezane s pamćenjem nisu apsolutne, nego su povezane s društvenom i povijesnom pozadinom. Stoga naša obveza sjećanja nije izolirana i bezuvjetna, nego dolazi uvijek u kontekstu naših drugih obveza, odnosno ona mora biti kontekstualizirana.

Nadalje, pamćenje je izvor moralnih obveza zbog svoje povezanosti s identitetom. Jeffrey Blustein primjerice smatra da je identitet ključni element unutar etike pamćenja jer je pamćenje povezano s identitetom, a identitet s dužnostima. Identitet je izvor dužnosti jer je identitet i normativna, a ne samo deskriptivna kategorija. Ili, kako to kaže Ross Poole,

normativna uloga pamćenja ovisi ponajprije o njezinoj povezanosti s nositeljem pamćenja [...]. Izvor normativnosti je pamćenja u njezinoj povezanosti s identitetom. Pamćenje uvijek dolazi u prvom licu. To je prošlost izgovorena iz perspektive onoga komu ona pripada. To je naša prošlost, i ako projicira našu sadašnjost u prošlost, mi imamo odgovornosti koje naša prisutnost donosi sa sobom (Poole, 2010, 34).

Pamćenje je oblik znanja koje se oslanja na subjekt (subject-centered knowledge). Događaji kojih se sjećamo pripadaju životu tog subjekta i zbog toga oni tomu istomu subjektu nameću odgovornosti. U tom je smislu normativnost pamćenja uvijek partikularna: ona se tiče odgovornosti koje taj specifični subjekt ili kolektivi imaju na temelju onoga što su oni učinili ili propustili učiniti u prošlosti. 


\section{O dužnosti pamćenja}

Pitanje dužnosti pamćenja i odgovornosti za prošlost šire je raspravljano s obzirom na kolektivnu razinu. No prvo recimo nešto o individualnoj razini i što to znači da se pojedinac mora, ako se mora, sjećati i preuzeti odgovornost za svoju prošlost. Čega se konkretno mora sjećati i kako to činiti?

U razdoblju predmoderne etičko je ponašanje bilo shvaćeno kao strogo prianjanje uz društvene i religijske standarde ponašanja. Kao i općenito s vrijednostima, etički i moralni standardi bili su ustanovljeni u nekoj (često mističnoj) dalekoj prošlosti. Oni dolaze od boga ili bogova, utemeljitelja, zakonodavaca, proroka ili svetih ljudi koji su pojasnili što se misli pod dobrim ili zlim. Zadatak pojedinca nije bio ispitivati vrijednost onoga što mu je predano, nego internalizirati zapovijedi i zabrane, i kada one postanu komponenta njihova ja, djelovati po njima kao unutarnjim imperativima. Osoba koja se ne samo sjećala savjesnije od drugih u skladu s društvenim ili religijskim propisima, nego koja je i djelovala u skladu s njima, bila je smatrana najvišim tipom etičkog pojedinca, i stoga modelom koji bi drugi trebali slijediti. U tom smislu, pamćenje je bilo vrlo bitno za etiku. Povezanost etike i pamćenja postojala je i u antičkom razdoblju, ali su teolozi srednjega vijeka otišli nešto dalje u tom području. Tako Toma Akvinski, primjerice, smatra etičko ponašanje mogućim zato što ljudi posjeduju jedinstvenu kvalitetu razboritosti, odnosno »sposobnost da donose moralne sudove«. Samo tamo gdje postoje moralne prosudbe, kaže on, postoje dobri i loši moralni izbori, i samo tamo gdje postoje pravi izbori, može postojati moralno ponašanje. Prema Tomi Akvinskom razboritost je vrlina prijeko potrebna u ljudskom životu. Za dobro djelovanje nije dostatno samo ono što čovjek radi, nego je važno i kako to radi, odnosno da to radi iz pravog izbora. Za to je potrebna intelektualna vrlina, odnosno razboritost. Ipak, kako je Toma rekao, bez jakog pamćenja razboritost ne bi bila moguća. Kako bi razboritost ili prudentia omogućila izvođenje zadaća koje je Bog naumio, mora postojati akumulirano i sačuvano znanje te iskustvo s kojim će osoba djelovati. Samo tamo gdje postoji »dobro opremljeno pamćenje « (za srednjevjekovne autore, što bolje pamćenje to bolje), može postojati dovoljno informacija koje treba razmotriti kako bi se došlo do moralne odluke (Toma Akvinski, 1985). Suprotno tomu, osoba čije je pamćenje slabo ili nerazvijeno imala bi poteškoća u etičnom djelovanju, jer ne bi imala ništa supstancijalno o čemu bi razmišljala i na temelju čega bi dosegnula moralnu prosudbu. U razdoblju predmoderne stoga je uzeto zdravo za gotovo da su oni pojedinci koji su imali bolje mentalne "navike zadržavanja" i koji su znali bolje kako pamćenja učiniti "integralnim i osposobljavajućim” mogli pokazati višu moralnu i etičku kvalitetu i kulturu (Gross, 2000, 26-27).

Tvrdnja kako pamćenje pomaže moralnomu rasuđivanju čini se razumljivijom u odnosu na strogo normativnu tvrdnju prema kojoj pamćenje, u nekim slučajevima, jest naša dužnost. Takva tvrdnja na prvi je pogled zbunjujuća, jer obveza nekog djelovanja i moralne odgovornosti pretpostavlja mogućnost izbora i dobrovoljni pristanak, a pamćenje kao da na neki način izmiče našoj kontroli. 
Ipak, mi hvalimo nekoga što se sjetio i kudimo ga što je zaboravio. Stoga za početak recimo da moralni imperativ ima smisla ako ni za što drugo, ono zato što naše moralne obveze traju u protoku vremena i imaju implikacije na naše buduce ponašanje, odnosno, da bismo ih ispunili, moramo ih se sjećati (kako sugerira i Toma Akvinski).

Što se pak tiče kontrole pamćenja, kada govorimo o "etici pamćenja”, tada mislimo na ono što Proust u svojoj knjizi $U$ potrazi za izgubljenim vremenom razlikuje kao voluntarističko i nevoluntarističko pamćenje. Prva su ona o kojima svjesno razmišljamo i odnose se na važne situacije u našem životu. Možemo ih nazvati formativnim pamćenjima, koja zahtijevaju neki naš stav prema njima, dakle promišljanje i svjesno odlučivanje te u odnosu na njih postoje načini kontrole pamćenja. Druga se tiču događaja koji nam bez naše kontrole jednostavno "padnu na pamet" i za njih se ne možemo smatrati odgovornima.

Što se tiče kolektivne razine, institucije i zajednice nemaju biološki ili antropološki temelj pamćenja te stoga one, kako to kaže Aleida Assman, ne "posjeduju", nego "grade" pamćenja. Taj proces izgradnje pamćenja upravljan je voluntarističkom politikom pamćenja i različitim sredstvima koja društva imaju na raspolaganju kako bi osigurala da njihovi članovi ne zaborave važne povijesne događaje i oblikuju kolektivno pamćenje.

Podizanje spomenika, građenje muzeja i održavanje komemoracija načini su kojima se upravlja kolektivnim pamćenjem, premda njihova efikasnost opada protokom vremena. Povijest je prepuna primjera hotimičnog nastojanja moćnika da kontroliraju pamćenje i potiskuju istinu o prošlosti. Ali pamćenje također blijedi bez korištenja izravne manipulacije, posebno u netradicionalnim i visoko individualističkim društvima poput našega, kojima nedostaje snažan smisao za međugeneracijski kontinuitet $\mathrm{i}$ koja ne nude društvene strukture koje bi podupirale individualno pamćenje. Buduće generacije zaboravljaju ono na što su se sadašnje zavjetovale da će se sjećati, zbog društvenih i drugih promjena i zbog toga što je pamćenje nepostojano čak i unutar jednog individualnog života (Blustein, 2008, 13).

Stoga ukazivati na dužnost ili imperativ pamćenja znači reći da pojedinci ili zajednice moraju, kako to kaže Blustein, »učiniti napor « kako bi sačuvali prošlost, oni moraju poduzeti neke mjere kako bi se oduprli prirodnoj eroziji pamćenja koju uzrokuje protok vremena i umjetnoj eroziji koju uzrokuju ljudski čimbenici ili njihove institucije.

S obzirom na dužnost pamćenja nameću nam se dva temeljna pitanja: Zašto smo dužni nešto pamtiti i na što se konkretno odnosi ta obveza pamćenja, te tko je taj koji odlučuje što smo dužni pamtiti? O razlozima takve dužnosti Blustein razmišlja na sljedeći način: Kako bismo uopće razmišljali o pamćenju kao dužnosti, mi se moramo pitati koje će dobro iz toga proizići ili kakve koristi imamo od pamćenja. Česti odgovori na to pitanje su sljedeći: pamtiti se mora kako bismo ispravili štetu ili bili oprezniji u budućnosti i spriječili ono što se dogodilo u prošlosti. Ili: sjećanje promovira kolektivno pamćenje i pojedinačno liječenje. No ako se čini da pamćenje ne ispravlja ili ne štiti, tvrdnja da moramo pamtiti čini se kao sentimentalno prianjanje uz prošlost ili, još gore, mazohistička želja za prerađivanjem dijelova prošlosti koji se ne mogu izmijeniti, a što samo može prouzročiti 
dodatnu patnju ili društveni nemir. Dakle, argumenti koji podupiru tvrdnju o moralnoj dužnosti kolektivnog pamćenja uglavnom su konzekvencijalistički. U toj argumentaciji dužnost pamćenja opravdava se ulogom koju pamćenje ima unutar instrumentalne strukture vrijednosti (primjerice tko ne uči iz prošlosti, osuđen je na njezino ponavljanje i sl.). No Blustein smatra kako to nije dovoljno kada se govori o imperativu ili dužnosti pamćenja. On smatra da imamo odgovornost prema prošlosti, bilo u odnosu na ono što je bilo loše u prošlosti, bilo u odnosu na dobro, i da je konzekvencijalistički pristup više sklon onomu lošemu u prošlosti. On sugerira tzv. ekspresionistički pristup, prema kojem je pamćenje dobro po sebi, a dužnost sjećanja može se opravdati neovisno o tome koju ulogu ono može imati u smislu dobrih posljedica i sprječavanja loših. Blustein smatra da u nekim slučajevima, kad je pamćenje nekako prirodno (primjerice pamtimo svoje mrtve roditelje ili prijatelje zato što ih volimo, a ne zato što moramo) ekspresionistički iskaz dodaje obligatornost pamćenju, što je važno u odolijevanju eroziji pamćenja, do koje dolazi zbog protjecanja vremena (Blustein, 2008, 34-41). Podržavamo takav pristup u odnosu na imperativ pamćenja jer podržava šire shvaćanje moralnih obveza i dužnosti, te uzima u obzir tvrdnju da ono što je nekim skupinama od prošlosti "korisno" ili "iskoristivo", drugima može biti problematično i poticati društvene nemire.

\section{Odgovornost za prošlost i odgovornost pamćenja}

Dakle, moralna teorija o pamćenju, i odgovornostima koje su s tim povezane, mora uzeti u obzir dobro poznatu osjetljivost pamćenja i znati kako odgovoriti na nju. Tvrdnja koja propušta suočiti se s problemom manipulacije pamćenjem može se smatrati onom koja podupire sile društvene kontrole. Što se tiče naše osobne odgovornosti prema prošlosti, Blustein našu dužnost smješta unutar dužnosti koje imamo prema samima sebi. Naime, on smatra kako mi imamo osobnu odgovornost i prema svojoj osobnoj/privatnoj prošlosti i prema onoj kolektivnoj. A preuzeti odgovornost za prošlost možemo samo ako činimo napor pamćenja, odnosno ako se trudimo pamtiti. Na kolektivnoj pak razini preuzimanje odgovornosti za prošlost znači priznavanje prošlih nedjela, kajanje zbog njih, nuđenje odštete (ekonomske ili koje druge) žrtvama i njihovim potomcima. Ono može značiti i poštivanje ugovora koji su sklopljeni u prošlosti. Ti zadatci daju pamćenju moralno značenje: jer ne možemo preuzeti odgovornost za prošlost ako se nje ne sjećamo. Stoga oni koji su odgovorni za prošla zlodjela imaju moralnu obvezu da ih se sjećaju, kao što se i oni koji su vezani prethodnim ugovorima moraju njih sjećati. Nadalje, pamćenje je također važno za pojedince jer preuzimanje odgovornosti za prošlost ponajprije znači preuzimanje odgovornosti za ono što je netko učinio u prošlosti, ali i preuzimanje odgovornosti za sebe, odnosno za ono što smo postali (Blustein, 2008, 35-41). To uključuje prihvaćanje eventualnog dijela naše osobnosti koji nam se možda ne sviđa ili prekoravanje sebe zbog prošlih čina, jasnoću o vlastitoj odgovornosti u izgradnji karaktera i izbjegavanje isprike za to što smo postali, svijest da smo sposobni kontrolirati smjer nečijeg života te 
razumijevanje utjecaja prošlosti. Iz toga proizlazi da je preuzimanje odgovornosti za prošlost etički važno i poželjno, bez obzira radi li se o nečem lošem u prošlosti. Stoga odgovornost za osobnu prošlost nije samo nešto što je poželjno nego je i nešto što je katkad nužno, u najjačem smislu te riječi. Blustein tu dužnost odgovornosti za prošlost promišlja u okviru dužnosti prema samom sebi: netko ne može preuzeti odgovornost prema sebi ako ne preuzme i odgovornost prema svojoj prošlosti (posebno onim dijelovima koji čine osobnu prošlost i oblikuju identitet i samopoimanje osobe) (Blustein, 2008, 45-49). Pamćenje je stoga mediji kroz koji je neka vrsta moralnog odgoja uopće moguća. Stoga način na koji se netko sjeća prošlosti i kako su nečija pamćenja oblikovana velikim dijelom otkriva moralni profil te osobe (recipročni utjecaj pamćenja i identiteta). Ukratko: ako postoji dužnost preuzimanja odgovornosti za prošlost, možda shvaćene kao dužnost prema samom sebi, onda također mora postojati imperativ pamćenja te prošlosti, jer, u bitnoj mjeri, pamćenjem nam prošlost postaje dostupna.

\section{Pamćenje i trauma}

Poplava pamćenja nije fenomen jedinstven za naše doba, ona je pratilac svih većih kriza razdoblja moderne i postmoderne. Winter smatra da postoje dva velika vala sjećanja: jedan se dogodio krajem 19. i početkom 20. stoljeća, a imao je ulogu »izmisliti ili otkriti živopisnu prošlost koja bi stabilizirala političke oblike u nastajanju « (Winter, 2006, 25-26). Drugi se pojavio krajem 20. stoljeća, a obuhvaća brojna povijesna naslijeđa te integrira diskurs traume i krivnje. Norra kaže da je jedan val vezan uz stvaranje nacionalizma, a drugi uz njegovo opadanje. Kada se ruše neki metafizički ili simbolički potpornji, pribjegava se pamćenju kao riznici iz koje se nastoje iznjedriti neka usmjerenja i poučci. Zato je, smatra Misztal, i sadašnji trend pamćenja povezan s opadanjem uloge nacionalnog i religijskog pamćenja kao stabilnog izvora identiteta, te se ponovo otvara prostor za traženje i autentičnog identiteta i upotrebljive prošlosti (Mitzsal, 2003, 6784). Ono što je pak karakteristično za naše doba dva su fenomena: prvi je da zaokupljenost prošlošću »koincidira s nasiljem i grozotom u dvadesetom stoljeću, s rastućim moralnim zahtjevom da se ne zaboravi prošlost koja je bila nehumana i nepravedna « (Assman, 2013, 41), a drugi je aktualizacija nove paradigme paradigme globalizacije (Bajović, 2012, 91). Radstone također smatra kako je današnja poplava pamćenja velikim dijelom obilježena traumatskim pamćenjem te da »identifikacija s patnjom i žrtvama zbližava ljude kao nekad tradicionalni oblici političkih udruženja« (Radstone, 2008, 36).

Čini se zapravo da je velika većina radova koji se bave etičkim i političkim značenjem pamćenja na neki način pod utjecajem osobnih ili javnih događaja Holokausta ili na neki način Holokaust pruža kontekst za poslijeratno poimanje pamćenja. Bilo bi odveć jednostavno tvrditi da današnje zanimanje za pamćenje, u javnosti ili akademskoj zajednici, potječe samo otuda, no ta činjenica jednim dijelom objašnjava zašto je, kad se govori o pamćenju, uglavnom naglasak na dimenziji traume, a ne na "normalnom" pamćenju. Drugi je razlog sama 
priroda pamćenja traume. Traumatični događaji ekstremni su događaji, izrazito nabijeni emocijama, ostavljaju dublje ožiljke i imaju veću motivacijsku snagu. Takvi "složeniji” događaji iz našeg života automatski zahtijevaju i veći kognitivni angažman, pa se stoga bolje sjećamo tih događaja jer smo o njima više promišljali i s njima se više borili. Takvi događaji također, ako su prešućeni, paraliziraju čovjeka ili društvo i tjeraju ih da se kad-tad vrate u prošlost i tako priječe hod u budućnost. To je stoga jedan od razloga zašto pamćenje traumatskih i "ružnih" događaja ima neko privilegirano mjesto u području istraživanja o pamćenju. O "privilegijima" koje dolaze od traumatske prošlosti bilo je također puno govora zadnjih godina (Todorov, Ricoeur, Bruckner i dr.).

\section{Nova memorijska paradigma: pamćenje za budućnost}

Što više znanja imamo, možemo bolje oblikovati budućnost. Etika je dakle na poseban način zadužena za to da pamćenja, ma kako bolna i traumatična, osiguraju zajedničku sigurnu budućnost. Cilj je stoga taj da se kod pojedinca inspirira neki oblik moralne transformacije koja bi spriječila buduće nasilje i promicala demokratske vrijednosti. Etika to čini na način da nađe neku ravnotežu između pamćenja i kontrapamćenja i omogući pluralizaciju pamćenja, jer, kako kaže Ricouer, poštivanje drugog implicira prihvaćanje »različitosti pamćenja « (Ricoeur, 1999, 12-16). Ipak, etika to treba činiti na način da potakne stvaranje zajedničkog sjećanja, a time potakne i zajedničke emocije i viziju budućnosti. Ricoeur stoga naglašava da samo preko pamćenja možemo stvoriti budućnost te prenijeti vrijednosti i vjerovanja budućim generacijama, jer se »dužnost pamćenja ne tiče samo dubokog interesa za prošlost, nego se sastoji posebno u tome da prenesemo pravo značenje prošlih događaja budućim generacijama « (Ricoeur, 1999, 9). Primo Levi, koji je i sam preživio koncentracijski logor, smatra da Holokaust ima ponajprije etičko-političku važnost i da je ta dimenzija važnija od povijesne, zato što pamćenje zatvorenika i preživjelih čini stalno nesigurnom granicu između prošlosti i sadašnjosti, između podsvijesti i svijesti. Stoga on ističe moralnu dužnost pamćenja ili svojevrsnu "etiku svjedočanstva” (Gordon, 2001).

Ipak, današnji dominantni narativi, potaknuti ranije spomenutim diskursom traume i krivnje, često ostavljaju krivi dojam da je pamćenje isključivo vezano uz prošlost i da zanemaruje budućnost. S druge strane, mnogi primjeri u svijetu ukazuju na nastajanje nove, prema budućnosti okrenute paradigme komemoriranja, koja nastoji upotrijebiti znanje iz prošlosti — posebno iskustvo trauma i nasilja — kako bi stvorila bolju sadašnjost i budućnost. Događa se, dakle, "promjena memorijske paradigme" (Bickford i Sodaro, 2010): sada se naglašava proučavanje prošlosti s jednim okom prema budućnosti. Mjesta žalovanja i tuge postala su mjesta koja nastoje spriječiti da se nasilje ponovo dogodi, odnosno postala su mjesta koja se pozivaju na snagu pamćenja kao instrument političkoga i građanskog aktivizma orijentiranoga prema budućnosti. Proliferacija kršenja ljudskih prava nakon Holokausta, posebno u Latinskoj Americi u osamdesetima i Južnoj Africi u devedesetim godinama 20. stoljeća dodatno je ojačala taj 
novi model pamćenja koji nastoji integrirati prošlost u sadašnjost i budućnost. Premda je oplakivanje mrtvih uvijek bilo u srcu svih memorijala, ono što je novo jest da to oplakivanje dobiva javni oblik, potiče se i simbolična, katkad čak i ekonomska reparacija za pojedince, skupine, društva i nacije, javno priznanje patnje i sankcioniranje počinitelja. Brojnija su također istraživanja o odgovarajućim edukacijskim i društvenim instrumentima suočavanja s prošlošću i učinkovitim kanalima prenošenja pamćenja kroz generacije, posebno pamćenje traume. Sve češće otvaranje memorijalnih i eksperimentalnih muzeja također je način odgajanja posjetitelja i prenošenje svijesti o tome kako je prošlost povezana s našim zamišljanjem budućnosti i kako naše vizije o budućnosti determiniraju način na koji se mi sjećamo prošlosti. Tako nova paradigma gledanja na prošlost sve više postaje agenda društvenih, kulturnih i političkih aktera današnjice, posebno aktivista za ljudska prava i promicanje demokracije, koji se nadaju da će suočavanje s prošlošću pomoći u izgradnji bolje budućnosti. Stoga se sve više čini da politički legitimitet u suvremenom svijetu počiva na suočavanju s prošlošću i memorijali su bitni mehanizam za legitimiranje nacija u očima međunarodne zajednice: bilo da priznaju prošle zločine bilo da pokažu volju za učenjem iz prošlosti.

Usporedo s takvim pozitivnim promjenama u shvaćanju prošlosti i pamćenja sve više teoretičara ističe i političku zlouporabu suočavanja i ophođenja $s$ pamćenjem kada se ono koristi kao politički instrument, nešto poput nekadašnjih "izmišljenih tradicija" (Hobsbawm i Ranger) koje su išle za tim da konstruiraju nacionalna mjesta pamćenja koji inkorporiraju verzije prošlosti u svrhu kontrole sadašnjosti i budućnosti od strane režima. Premda je nakon Holokausta porastao onaj potencijal pamćenja “nikad više”, mnogo je razloga za skepsu, kao što su to opisali Peter Novick i Norman Finkelstein u vezi s komemoriranjem Holokausta (Novik, 2008; Finkelstein, 2006).

Nadalje, prednost u upravljanju pamćenjima sve se više daje organizacijama civilnog društva i građanskim udrugama, kao onima koje veću pozornost pridaju žrtvama i njihovu iskustvu. Na arbitrarnost državnog upravljanja procesom pamćenja i komemoriranjem upozorio je već davno i Nietzsche, koji je predvidio da će prošlost biti korištena za nacionalno jedinstvo i ponos, a pojedinačna pamćenja gotovo nasilno ugurana u univerzalni kalup (Nietzsche, 1980). Drugim riječima, upozorio je na potencijal pamćenja za osnaživanje hegemonijskih nacionalnih narativa i njihovo nastojanje da spriječe ili čak izbrišu mala, "obična", lokalna pamćenja.

Koncept takvih "malih, običnih pamćenja" koja su povezana sa subnacionalnim identitetima ima korijene u memorijalnim projektima nakon Prvoga svjetskog rata, kada se počela pridavati nova pozornost tzv. malim ljudima te se oni integriraju u memorijale, a njihova imena stavljaju na grobove, spomenploče i dokumente (nekad je bilo nezamislivo da se na spomen-ploči pišu imena svih boraca te su se samo navodili vojskovođe, a ostali su bili bezimeni, no danas je to uobičajena praksa). Smisao takve prakse jest da se u skupinama naglasi vlastito samoodređenje i da se posebno značenje dade njihovim iskustvima kao zajedničkim iskustvima, kako bi se ujedno povezali i razlikovali od drugih. Ta 
nova pozornost prema pojedincima označila je proces demokracijskog trenda u pamćenju. Memorijali počinju odražavati novi smisao jednakosti i uključivosti, a pojedinci i osobne žrtve počinju se smatrati vrijednima komemoriranja i imenovanja, te na neki način postaju riznica nacionalne baštine kao i inspiracija za umjetnike (popularnost povijesnih i biografskih filmova).

Novi trend "privilegiranja žrtava" koliko god po sebi često paradoksalan (u smislu da se nauštrb žrtava iz prošlosti stvaraju nove žrtve u sadašnjosti), ipak je pomogao da manjinske ili druge rubne skupine (Foucault naziva njihova pamćenja counter memory, hrv. kontrapamćenja ili protivpamćenja), koje su bile žrtve i nekoć bile gurnute u pozadinu, danas imaju veće javno priznanje. Nadalje, protagonisti nove memorijske paradigme vjeruju da je prevencija od zlouporaba moguća na nekoliko načina. Prije svega, oni ističu edukaciju i odgoj kao središnji alat jer vjeruju da učenje iz prošlosti može osigurati neponavljanje pogrešaka. Pedagogija pamćenja nalazi se u središtu njihove misije, a muzeji, posebno eksperimentalni, najbolji su primjer komemoracija kao edukativne aktivnosti. Kao drugo, naglašava se važnost postizanja iskustva učenjem, u smislu da posjetitelji muzeja ili slušatelji postanu emocionalno zahvaćeni pričama iz prošlosti, tzv. emotivno posjednuće ili emotional possession (filmska umjetnost tu ima vrlo važnu ulogu). Važno je dakle da posjetitelji imaju neko svoje "iskustvo" prošlosti, poput vremeplova i povratka kroz vrijeme. Eksperimentalni muzeji u kojima je moguće osjetiti miris nekog drugog doba, klaustrofobiju i sl., kako bi posjetitelji dobili osjećaj kako je to biti zatvoren, ili uprizorenje iskustva totalitarnog režima te ostavljanje porušenih gradova kao spomenika takvi su primjeri. Takvim eksperimentalnim učenjem i povezanošću s djelovanjem, odnosno tzv. service learning, potiče se prevencija budućih konflikata. Naposljetku, razvija se empatija prema žrtvama prošlosti. Lynn Hunt u svojoj knjizi Inventing Human Rights ističe kako je empatija kao ljudsko iskustvo u korijenu izmišljanja ljudskih prava; odnosno, pojava empatije i pratece sposobnosti identifikacije s drugim u središtu je koncepta univerzalnih ljudskih prava (Hunt, 2007). Korištenjem odgojnih i eksperimentalnih tehnika nova memorijska paradigma potiče pojedince da se identificiraju sa žrtvama i da se "nauče" empatiji. Osjećajući empatiju prema žrtvama i donoseći prošlost u pojedinčevu sadašnjost, tako da ona nije daleka, nego donekle realna, nastoji se pojedinca moralno preobraziti i internalizirati imperativ "nikad više". Već spomenuto imenovanje žrtava čini te žrtve ljudskijima u očima posjetitelja i inspirira neki oblik identifikacije. Small-scale memorijali nastoje posjetitelja staviti u žrtvine cipele, na tragu onoga što je vjerovao Adorno: da je "hladnoća" razuma ono što se nalazi u srcu modernog društva i njegova najgoreg momenta — Auschwitza (Adorno, 1967).

Unatoč svim tim nastojanjima da se prošlost, posebno traumatična, iskoristi za izgradnju bolje budućnosti, teško je pouzdano izmjeriti učinak takvih aktivnosti. Dok se potiče pedagogija pamćenja i empatija, ostaje pitanje transformira li se to znanje uistinu u djelovanje. No, kako kažu Bickford i Sodaro, barem prividno slaganje ili svjetski konsenzus oko toga da možemo učiti iz prošlosti daje nadu u bolju budućnost (Bickford i Sodaro, 2010, 82). Skepsa oko toga hoće li učenje o 
prošlosti spriječiti zlodjela u budućnosti ostaje, ali ono što možemo ustvrditi jest da se pamćenje u novoj memorijskoj paradigmi sve više upotrebljava na način da odražava sadašnje želje i ideale za budućnost. Samo će budućnost pokazati je li ta paradigma bila uspješna.

\section{Zaključak}

Hrvatsko se društvo na poseban način čini obilježeno Ricoeurovom rečenicom kako na jednoj strani imamo previše sjećanja, a na drugoj previše zaborava. Uz političku manipulaciju pamćenjima svojstvenu totalitarnim režimima, čije posljedice osjećamo i danas, događa se proces svojstven drugim demokratskim sustavima, a to je atrofija pamćenja i proces privatizacije pamćenja, koji se konkretizira kao pluralizacija pamćenja (Hervieu-Léger, 2000, 124-127). Kako je prethodno spomenuto, pluralizacija pamćenja dio je demokratskog sustava i poželjna je u našem društvu, ali u Hrvatskoj je problematično to što jedna pamćenja, vezana uz pozicije moći, isključuju druga. Takva neravnopravnost pamćenja, njihova disperzija usporedo s globalizacijskim procesom otežava učinkovito djelovanje kolektivnog pamćenja u postizanju društvene kohezije te kooperaciju između različitih društvenih skupina.

Nadalje, samo propitivanje mogućnosti raščišćavanja s prošlosti još uvijek se smatra retrogradnim i nečim što koči napredak i hod u budućnost. Tako se one koji naglašavaju važnost suočavanja s prošlošću etiketira kao konzervativce, a one koji ignoriraju prošlost smatra se progresivnima. No radi se zapravo o paradoksu, što smo nastojali pokazati u ovom radu. Stalne rasprave i tenzije između jednih i drugih idu u prilog tezi da se prošlosti ne možemo osloboditi, posebno ako je neraščišćena, te i sadašnjost i budućnost stoje na nesigurnim temeljima. Brojni konkretni primjeri iz svijeta, kao i iz naše nacionalne povijesti, zorno svjedoče o razmjerima opasnosti neukroćenih pamćenja. Stoga važnost "pedagogije pamćenja" u smislu poticanja svih društvenih skupina da razviju refleksivno pamćenje kako bi osnažili recipročno povjerenje, postaje sve dominantnijom temom.

\section{Literatura:}

Adorno, Theodor W. (1967). Prisms. Cambridge: MIT.

Assman, Aleida (2013). Transformations of Modern Time Regimes. U: Chris Lorenz i Berber Bevernage (ur.), Breaking up Time: Negotiating the Borders between Present, Past and Future (str. 39-56). Göttingen: Vandenhoeck\&Ruprecht.

Bajović, Tijana (2012). Poplava sećanja: nastanak i razvoj memory booma. Filozofija $i$ društvo, 23(3), 91-105.

Barman, Jean (1997). žI walk my own track in life \& no mere male can bump me off it': Constance Lindsay Skinner and the Work of history. U: Beverly Boutilier i Alison Prentice (ur.), Creating Historical Memory: English-Canadian Women and the Work of History (str. 129-163). Vancouver: University of British Columbia.

Bell, Duncan (2009). Introduction: Violence and Memory. Millennium: Journal of International Studies, 38(2), 345-360. 
Bickford, Louis; Sodaro, Amy (2010.). Remembering Yesterday to protect Tomorrow: The Internationalization of a New Commemorative Paradigm. U: Yifat Gutman, Adam Brown i Amy Sodaro (ur.), Memory and the Future: Transnational Politics, Ethics and Society (str. 66-86). Hamphsire: Palgrave Macmillan Memory Studies.

Blustein, Jeffrey (2008). The Moral Demands of Memory. Cambridge: Cambridge University.

Booth, W. James (2006). Communities of Memory: On Witness, Identity, and Justice. Ithaca: Cornell University.

Brkljačić, Maja; Prlenda, Sandra (ur.) (2006). Kultura pamćenja i historija. Zagreb: Golden Marketing.

Finkelstein, Norman G. (2006). Industrija Holokausta: Razmišljanje o izrabljivanju židovske patnje. Zagreb: Hasanbegović Zlatko.

Gordon, Robert S. C. (2001). Primo Levi's Ordinary Virtues: From Testimony to Ethics. Oxfrod: Oxford University.

Gross, David (2000). Lost Time: On Remembering and Forgetting in Late Modern Culture. Boston: University of Massachusetts.

Hartley, Leslie Poles (1953). The Go-Between. Harmondsworth: Penguin Books.

Hervieu-Léger, Danièle (2000). Religione e memoria. Bologna: Il Mulino.

Hunt, Lynn (2007). Inventing Human Rights: A History. New York: Norton \& Company.

Huyssen, Andreas (1995). Twilight Memories: Marking Time in a Culture of Amnesia. London: Routledge.

Kearney, Richard (2004). On Paul Ricoeur: The Owl of Minerva. Aldershot: Ashgate.

Lewis, Bernard (1975). History: Remembered, Recovered, Invented. Princenton: Princenton University Press.

Lowenthal, David (1995). The Past is a Foreign Country. Cambridge: Cambridge Univeristy.

Midgley, Mery (2000). The Origin of Ethics. U: Peter Singer (ur.), A Companion to Ethics (str. 3-14). Oxford: Blackwell Publischers.

Mitzsal, Barbara (2003). Theories of Social Remembering. Berkshire: McGraw Hill Education.

Nietzsche, Friedrich (1980). On Advantage and Disadvantage of History for Life. Cambridge: Hacket Publishing Company.

Novik, Peter (2008). The Holocaust in American Life. Boston: Houghton Mifflin Company.

Olick, Jeffrey K. (2003). Introduction. U: Jeffrey K. Olick (ur), States of Memory: Continuities, Conflicts, and Transformations in National Retrospection. Durham: Duke University.

Poole, Ross (2010). Misremembering Holocaust: Universal Symbol, Nationalist Icon or Moral Kitsch? U: Yifat Gutman, Adam Brown i Amy Sodaro (ur.), Memory and the Future: Transnational Politics, Ethics and Society (str. 31-49). Hamphsire: Palgrave Macmillan Memory Studies.

Radstone, Suzane (2008). Memory nad Methodology. Oxford: Berg Publishers.

Ricoeur, Poul (1999). Memory and Forgetting. U: Richard Kearney i Mark Dooley (ur.), Questioning Ethics: Contemporary Debates in Continental Philosophy (str. 1-7). London: Routledge.

Rosenfeld, Gavriel D. (2009). A Looming Crash or a Soft Landing? Forecasting the Future of the Memory "Industry". The Journal of Modern History, 81(1), 122-158.

Scanlan, John (2015). Pamćenje: Susreti s nepoznatim i poznatim. Zagreb: TimPress. 
Toma Akvinski (1985). Sentencia libri De sensu et sensato cuius secundus tractatus est De memoria et reminiscencia. Rim: Leonina.

Volf, Miroslav (2006). The End of Memory: Remembering Rightly in a Violent World. Cambridge: William B. Eerdmans.

Vosloo, Robert (2012). Memory, History and Justice: In Search of Conceptual Clarity. Nederduitse Gereformeerde Teologiese Tydskrif, (Supplementum 3), 53, 215-227.

Winter, Jay (2006). Remembering War: The great War and Historical Memory in the 20th century. London: Yale University.

Yerushalmi, Yosef Hayim (1982). Zakhor: Yewish History and Jewish Memory. Seattle: University of Washington.

\section{Memory in the Service of the Future}

\section{Jasna Ćurković Nimac*, Jerko Valković**}

\section{Summary}

In recent years, interest in memory studies has increased, though we are still witnessing an apparent lack of systematic insight into the ethical dimension of this subject. The purpose of this paper is to shed light on some aspects of the ethics of memory. Hence, apart from the cognitive and epistemological dimensions of memory, the authors of this paper pay special attention to the normative and formative dimensions of memory. Bearing in mind that the connection between memory and identity is a key source of normativity, the authors strive to demonstrate that social and political stability depends on how one relates to memory.

The first section of the paper examines certain phenomenological assumptions which need to be considered when discussing memory. The second section analyses the correlation between memory and moral values and responsibilities. The authors claim that memory is a good thing, and therefore a valuable part of life, and so they highlight certain ethical criteria of memory that should ensure the "future of memory". With due concern for memory manipulation, the paper underlines positive advancements in the evolution of the memory paradigm at the end of the 20th century.

Key words: ethics, memory, future, society, justice

* Jasna Nimac Ćurković, Ph. D., Associate Professor. Croatian Catholic University. Address: Ilica 242, 10000 Zagreb, Croatia. E-mail: jasna.curkovic@unicath.hr

** Jerko Valković, Ph. D., Associate Professor. Croatian Catholic University. Address: Ilica 242, 10000 Zagreb, Croatia. E-mail: jerko.valkovic@unicath.hr 